\title{
Comparisons of Cocoa Pod Husks and other Biomass Wastes for Syngas Production
}

\author{
Anthony Ademola Adeyanju ${ }^{*}$ \\ ${ }^{1}$ Department of Mechanical and Manufacturing Engineering, The University of the West Indies, St. Augustine Campus, Trinidad and \\ Tobago
}

\begin{abstract}
In this study, the characteristics of sawdust, switch grass, cocoa pod husks, and bagasse were investigated and compared, as well as the effects of blended nickel and silicon dioxide catalysts on syngas production by gasification utilising a fluidised bed reactor. Because of their high volatile matter and cellulose content as well as low moisture content, sawdust, switch grass, cocoa pod husks, and bagasse were found to be appropriate for generating syngas. Experimental analysis was conducted on the sawdust, switch grass, cocoa pod husks and bagasse samples with and without catalyst. The grains in the samples were comparable in size, ranging from $2 \mathrm{~mm}$ to $6 \mathrm{~mm}$. The catalysts were revealed to have a distinct influence on the gasification process. The efficiency of the processes improves with catalysts, while the generation of $\mathrm{CO}$, $\mathrm{CO}_{2}, \mathrm{HC}$, and $\mathrm{NO}$ decreases. Cocoa pod husks produced the highest $\mathrm{HC}$ value of $7928 \mathrm{ppm}$ without catalysts while bagasse produced $1679 \mathrm{ppm}$ that is the lowest $\mathrm{HC}$ value.
\end{abstract}

\section{Introduction}

Municipal solid waste and biomass feedstock are both plentiful and underutilised energy sources. Using the energy content of these feedstock's, which is renewable, has huge environmental, economic, and societal implications. While mass combustion has long been the preferred means of generating heat and power, thermochemical processes such as pyrolysis and gasification open up various options, such as fuels transportation, chemicals and synthetic natural gas [1]. Given the need to discover fossil fuels alternatives and decrease $\mathrm{CO}_{2}$ emissions, is becoming increasingly significant [2]. For millennia, thermochemical processes have been understood and applied. As early as the 19th century, pyrolysis and gasification of coal were used as examples [3], [4]. Coal pyrolysis yielded coke and coal gas, whereas coal gasification yielded a combustible gas known as synthetic gas (syngas) or producer gas.

Although this sordid history, thermochemical methods for processing biomass and waste materials have only recently emerged, spurred on by the need for conservation of resources and more effective energy recovery. Biomass and waste, for example, make up a miniscule fraction of the feedstock handled by gasification facilities across the world, with fossil fuels accounting for the vast majority of synthesis gas output. Regardless, thermo - chemical treatment of biomass feedstock's, including solid waste, holds a lot of potential in and of itself. By converting low or negative value feedstock into marketable fuels and products, they add value to it [5]. Furthermore, while waste materials can be difficult to work with, they offer certain economic advantages over other biomass. For example, most garbage sources are subject to a gate fee for disposal; collection systems are frequently developed, with the waste producer bearing the cost. Finally, unlike certain biomass sources, waste does not compete with the production of food [6]. Because of their versatility and high conversion efficiency, fluidised beds have long been employed in the thermal analysis of fuels from solid waste. They still have potential for deploying newgeneration thermochemical treatments for improved biofuel production quickly.

Solid waste may be converted into fuel in two methods. The first is biochemical, which is accomplished through the breakdown of organic materials by organisms. The drawbacks of this approach are the high cost of catalysts, the extensive preconditioning of feed, and the production of a specific product (for example ethanol) [7], [8]. The second approach is thermochemical conversion of biomass waste into fuel, which is accomplished by heating biomass to temperatures between $500^{\circ} \mathrm{C}$ and $850^{\circ} \mathrm{C}$ in the presence of air, oxygen or steam. In the presence of oxygen, this process is known as gasification, while in the absence of oxygen, it is known as pyrolysis. High temperatures allow the cellulosic material to degrade producing synthesis gas ("syngas"), a combination of gases such as hydrogen and carbon monoxide.

Syngas is the resultant gas from gasification and it consists of carbon monoxide and hydrogen together with carbon dioxide and methane. After going through many procedures, this gas is employed in various applications [9]. The primary benefits of this method are the cheap cost of waste and the ability to recycle it. Gasification is comparable to the burning; however, it is

* Corresponding author: anthony.adeyanju @ sta.uwi.edu 
an incomplete combustion process that produces less carbon dioxide (greenhouse gas) [10].

This research aims to compare the production of syngas from sawdust and other biomass wastes, as well as to look into the impacts of mixed Nickel and Silicon dioxide catalysts on syngas production by gasification utilizing a fluidized bed reactor.

\section{Fluidized Bed Gasifier Theory}

A gasification agent is blasted across a bed of solid particles in order for the bed material and the particles to remain in a condition of suspension at a suitable velocity in a fluidized-bed gasifier [11]. The feedstock is fed into the reactor at the bottom, where it is mixed with the bed material before being quickly heated to the bed temperature. The feedstock is pyrolyzed quickly because of the heat. Figure 1 depicts several zones and reactions that occur in a gasifier.

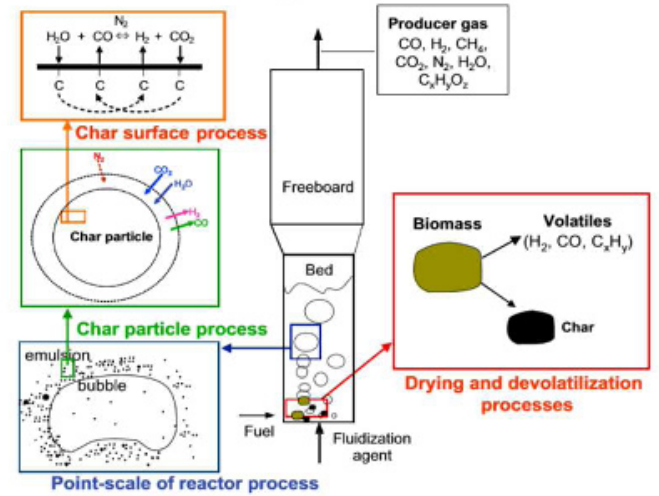

Fig 1: Reactions that occur in a gasifier (fluidised bed) [12]

\subsection{Gasification}

Gasification can be defined as the thermochemical conversion of chemical feedstock into a gaseous fuel which can be utilised to generate valueadded chemicals [13]. Partial combustion of biomass generates combustible gases such as hydrogen $\left(\mathrm{H}_{2}\right)$, methane $\left(\mathrm{CH}_{4}\right)$, and carbon monoxide $(\mathrm{CO})$ in small amounts, as well as tar and dust [14]. Syngas, or synthesis gas, is the name given to the gases that are produced. Producer gas is created when noncombustible gases such as carbon dioxide $\left(\mathrm{CO}_{2}\right)$ and nitrogen $\left(\mathrm{N}_{2}\right)$ are generated during gasification. Syngas, which has a 50 percent higher energy density than natural gas, is utilised as an intermediary in the industrial synthesis of ammonia and hydrogen, as well as a fuel source.

To avoid softening of the bed material, gasification of this type of biomass material in a fluidised bed favours temperatures in the range of $700^{\circ} \mathrm{C}-900^{\circ} \mathrm{C}$, according to [13]. The author says that the solid feedstock can be converted into liquids or gases using a gasification medium such as air, steam, or oxygen. Because of the process, hydrogen is added to the biomass feedstock while carbon is removed, resulting in a greater hydrogen-to-carbon $(\mathrm{H} / \mathrm{C})$ ratio in the syngas generated. The gasification process includes the following steps:

(i) Drying - Before entering the gasifier, the feedstock must be pre-dried to eliminate moisture. The moisture level of the product is between $5 \%$ and $35 \%$. The feedstock is dried even further when it gets heat from the gasifier's hot zone.

(ii) Pyrolysis devolatilisation and combustion Organic compounds are thermochemically destroyed at elevated temperatures without the need of an external agent during this process. Because of this breakdown, solid charcoal (Char) and tar, as well as condensable and non-condensable gas molecules, are produced. The feedstock is prepared for combustion in this step.

(iii) Char gasification - When pyrolysis produces biomass char, it is not necessarily pure carbon. It has a little quantity of hydrocarbon, which is made up of hydrogen and oxygen. A process that occurs during the gasification of biomass char is oxidation, which involves char and the gasification media. This process happens when solid carbonised biomass or char comes into contact with oxygen, resulting in the production of $\mathrm{CO}_{2}$. The hydrogen in the biomass is oxidised to create water, according to [11]. The authors say that when carbon and hydrogen are oxidised, heat is produced.

At $25^{\circ} \mathrm{C}$, the presence of $\mathrm{O}_{2}$ in sub stoichiometric concentrations causes partial oxidation of carbon, which produces carbon monoxide. Table 1 demonstrates the different processes that occur when oxygen, hydrogen and carbon dioxide come into contact with the generated char.

\subsection{Gasifying Agents}

For the conversion of solid biomass to gases, gasification agents are required. The agents influenced the heating value of the resultant gas. Air, steam, and oxygen are the three most frequent media utilised in this process. Although air is a cheap and frequently used gasifier, it includes nitrogen, which reduces the calorific value of the syngas generated [11].

They further claim that partial combustion of biomass with air produces heat for drying and increases the temperature of the biomass, which stimulates endothermic processes. Its heating value was estimated to be approximately $46 \mathrm{MJ} / \mathrm{m}^{3}$.

The superheated type of steam gasification is an endothermic process. It can also be used with oxygen or air. It contributes to the production of hydrogen, which results in a greater $\mathrm{H} / \mathrm{C}$ ratio, according to [13]. The heating value of the produced gas has been raised to between 10 and $15 \mathrm{MJ} / \mathrm{Nm}^{3}$ [11].

Oxygen is required for partial gasification, and it is delivered in its purest form through air [13]. The author says that when a little amount of oxygen is used, the resultant gas contains carbon monoxide, but when a large amount is used, the gas contains carbon monoxide. The maximum calorific value in the range of $10-18 \mathrm{MJ} / \mathrm{Nm}^{3}$ occur because of oxygen, which supplies the thermal energy necessary for endothermic gasification processes [15]. While a greater heating value is desirable, the cost of operation will rise owing to the expense of generating $\mathrm{O}_{2}$. 
Table 1 : Gasification reactions [13]

\begin{tabular}{|c|c|}
\hline Reaction Type & Reaction \\
\hline \multicolumn{2}{|l|}{ Carbon Reactions } \\
\hline R1 (Boudouard) & $\mathrm{C}+\mathrm{CO}_{2} \leftrightarrow 2 \mathrm{CO}+172 \mathrm{~kJ} / \mathrm{mol}^{2}$ \\
\hline R2 (water-gas or steam) & $\mathrm{C}+\mathrm{H}_{2} \mathrm{O} \leftrightarrow \mathrm{CO}+\mathrm{H}_{2}+131 \mathrm{~kJ} / \mathrm{mol}^{\mathrm{b}}$ \\
\hline R3 (hydrogasification) & $\mathrm{C}+2 \mathrm{H}_{2} \leftrightarrow \mathrm{CH}_{4}-74.8 \mathrm{~kJ} / \mathrm{mol}^{b}$ \\
\hline R4 & $\mathrm{C}+0.5 \mathrm{O}_{2} \rightarrow \mathrm{CO}-111 \mathrm{~kJ} / \mathrm{mol}^{2}$ \\
\hline \multicolumn{2}{|l|}{ Oxidation Reactions } \\
\hline R5 & $\mathrm{C}+\mathrm{O}_{2} \rightarrow \mathrm{CO}_{2}-394 \mathrm{~kJ} / \mathrm{mol}^{\mathrm{b}}$ \\
\hline R6 & $\mathrm{CO}+0.5 \mathrm{O}_{2} \rightarrow \mathrm{CO}_{2}-284 \mathrm{~kJ} / \mathrm{mol}^{\mathrm{c}}$ \\
\hline R7 & $\mathrm{CH}_{4}+2 \mathrm{O}_{2} \leftrightarrow \mathrm{CO}_{2}+2 \mathrm{H}_{2} \mathrm{O}-803 \mathrm{kj} / \mathrm{mol}^{d}$ \\
\hline R8 & $\mathrm{H}_{2}+0.5 \mathrm{O}_{2} \rightarrow \mathrm{H}_{2} \mathrm{O}-242 \mathrm{~kJ} / \mathrm{mol}^{\mathrm{c}}$ \\
\hline \multicolumn{2}{|l|}{ Shift Reaction } \\
\hline R9 & $\mathrm{CO}+\mathrm{H}_{2} \mathrm{O} \leftrightarrow \mathrm{CO}_{2}+\mathrm{H}_{2}-41.2 \mathrm{~kJ}^{\prime} / \mathrm{mol}^{\mathrm{c}}$ \\
\hline \multicolumn{2}{|l|}{ Methanation Reactions } \\
\hline R10 & $2 \mathrm{CO}+2 \mathrm{H}_{2} \rightarrow \mathrm{CH}_{4}+\mathrm{CO}_{2}-247 \mathrm{kl} / \mathrm{mol}^{\mathrm{c}}$ \\
\hline R11 & $\mathrm{CO}+3 \mathrm{H}_{2} \leftrightarrow \mathrm{CH}_{4}+\mathrm{H}_{2} \mathrm{O}-206 \mathrm{~kJ}^{-\mathrm{mol}^{\mathrm{c}}}$ \\
\hline R14 & $\mathrm{CO}_{2}+4 \mathrm{H}_{2} \rightarrow \mathrm{CH}_{4}+2 \mathrm{H}_{2} \mathrm{O}-165 \mathrm{~kJ} / \mathrm{mol}^{b}$ \\
\hline \multicolumn{2}{|l|}{ Steam-Reforming Reactions } \\
\hline R12 & $\mathrm{CH}_{4}+\mathrm{H}_{2} \mathrm{O} \leftrightarrow \mathrm{CO}+3 \mathrm{H}_{2}+206 \mathrm{kl} / \mathrm{mol}^{\mathrm{d}}$ \\
\hline R13 & $\mathrm{CH}_{4}+0.5 \mathrm{O}_{2} \rightarrow \mathrm{CO}+2 \mathrm{H}_{2}-36 \mathrm{~kJ}^{-\mathrm{mol}^{\mathrm{d}}}$ \\
\hline
\end{tabular}

\subsection{Catalysts}

Solid impurities such as dust, sulphur compounds $\left(\mathrm{H}_{2} \mathrm{~S}\right)$, organic impurities such as tars, ash, inorganic impurities such as nitrogen and ammonia, and metal compounds must all be removed from the gaseous products produced by gasification [16]. These contaminants, especially tars, are carcinogenic and cause harm to downstream and process equipment. Physical methods, as well as thermal and catalytic cracking, can be used to remove them. Catalysts help by removing pollutants from the gas, as well as improving and influencing the yield and quality of Syngas or producer gas. Tar elimination processes are kinetically restricted, according to [16], therefore the rate of the reaction can be enhanced by changing the temperature and employing a catalyst as long as it is thermodynamically possible.

Catalysts can be used in two ways. The first method includes mixing it into the biomass, which allows the gasifier to remove the tar. In the second approach, the produced gas is treated downstream in a secondary reactor, where the tar is removed outside the gasifier. The former will be the major emphasis of this endeavour. The categories of catalysts, as well as some instances, are given below [16].

\subsubsection{Mineral Catalysts :}

These are naturally occurring and widely available, and they can be utilised alone or with physical therapy. They are reasonably priced. Here are a few examples :

(i) Calcined Rocks - These catalysts, also known as alkaline earth oxides, are made up of earth metal oxides such as $\mathrm{MgO}$ and $\mathrm{CaO}$, calcined dolomites, magnesite, calcite, and any metal from group $2 \mathrm{~A}$ of the periodic table. Because coke, which is produced because of catalytic reactions with tar, blocks the active pore sites in calcined rocks, the rocks become deactivated. Due to its low cost and high tar conversion rate of around $95 \%$, dolomite $\left(\mathrm{CaCO}_{3} \mathrm{MgCO}_{3}\right)$ is a common choice of catalyst. It converts tar to noncondensable combustible gases such as $\mathrm{H}_{2}$, $\mathrm{CH}_{4}$, and $\mathrm{CO}$, which are not considerably reformed [15].

(ii) Olivine - Olivine $\left((\mathrm{MgFe})_{2} \mathrm{SiO}_{4}\right)$ is composed of silicate minerals, and its tar elimination processes are comparable to those of calcined rocks. Coke formation deactivates it in the same way as calcined rocks do. When compared to dolomite, it has a lower tar conversion rate and, while it costs about the same, it has a better attrition resistance. As a result, it is more suited for usage in fluidized-bed settings.

(iii) Iron Ore - The shift process is catalysed by metallic iron in its reduced state. Due to the deposition of coke, it deactivates in the absence of hydrogen. These materials have lower levels of activity compared to dolomite.

\subsubsection{Synthetic Catalysts}

These catalysts are manufactured chemically, and they are costlier than mineral catalysts. Here are a few examples :

(i) Char: When biomass is pyrolysed, char is produced, and the catalytic activity of the char is influenced by mineral concentration, surface area, and pore size.

(ii) Alkali Metal-Based Catalysts: These metals, such as potassium (K), and sodium $(\mathrm{Na})$ are all members of the periodic table's group 1A. They are well-suited catalysts for $\mathrm{CO}_{2}$ and $\mathrm{H}_{2} \mathrm{O}$ gasification of carbon and are commonly employed in the form of metal carbonates.

(iii) Activated Alumina: When compared to dolomite, this catalyst $\left(\left(\mathrm{Al}_{2} \mathrm{O}_{3}\right) \quad \mathrm{OH}_{2}\right)$ deactivate more quickly due to the scoke production, but its catalytic activity is similar.

(iv) Transition Metal-Based Catalysts - These catalysts are suitable for steam and dry methane-reforming processes. Nickel (Ni) is the most common catalyst in this category, and it is employed as a support material because of its position as an active site and its resistance to heat and attrition. Alkali metals and alkaline earth metals are commonly used to boost the catalyst activity. It is great for speeding up steam reforming and shift reactions, removing tar, and converting tar to methane, which doubles the output of carbon monoxide and hydrogen [15].

\section{Materials and Methods}

\subsection{Preparation of samples used for experimentation}


The sawdust sample for this investigation was from a carpentry workshop at the University of the West Indies (UWI), Trinidad. The bagasse, cocoa pod and switch grass samples were obtained from Faculty of Agriculture (UWI) as shown in Figure 2.

Cocoa pod husk (CPH) is a by-product of the cocoa industry that is produced after the cocoa beans have been removed from the fruit. The pod husk accounts for 52 $76 \%$ of the weight of the cocoa fruit [17]. Ten tonnes of cocoa pod husks are produced for every tonne of dry beans produced, posing a major waste management problem [18]. Bagasse is the dry pulpy residue left behind after sugar cane juice is extracted. Bagasse is currently primarily utilised as a fuel in the sugarcane sector to meet its own energy needs. Switch grass is a tall North American panic grass that is used as a feedstock for biomass energy production.

To reduce the moisture level of the samples, they were dried outside at an average temperature of around $30^{\circ} \mathrm{C}$. After that, the samples were milled to the size required by the analysis equipment. Before analysis, the dried and milled samples were stored in a desiccator.

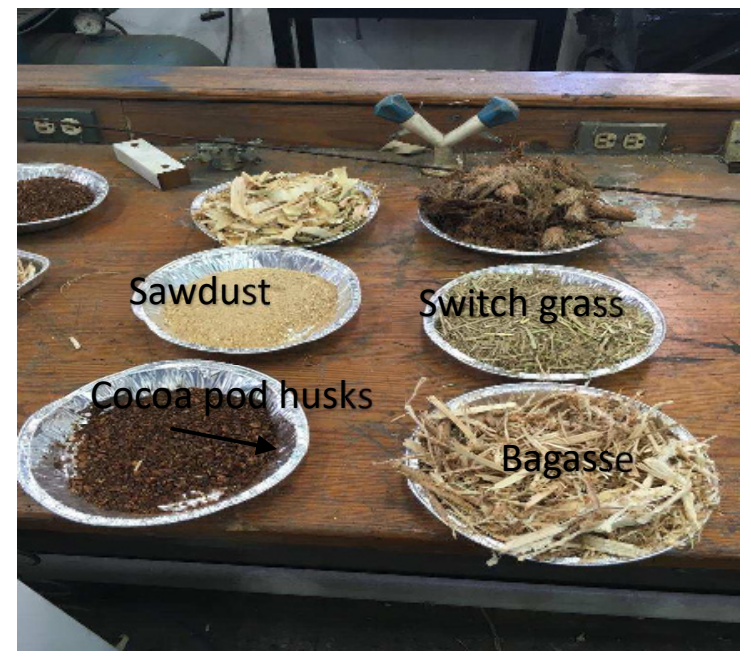

Fig. 2. Samples used for experimentation

\subsection{Proximate Analysis of the samples}

Proximate analysis provided the information needed for volatile matter, moisture, ash, and fixed carbon content of samples. These characteristics are important for the thermal conversion of any biomass into energy [19].

\subsection{Ultimate Analysis of the samples}

This study gave qualitative and quantitative information on the samples' elemental components. A Thermo Quest CHNS elemental analyzer was utilised. Hydrogen $(\mathrm{H})$, carbon $(\mathrm{C})$, nitrogen $(\mathrm{N})$ and sulphur $(\mathrm{S})$ proportions were measured, and oxygen (O) was calculated based on the difference. The mass fractions of the constituent components acquired from CHNS analysis, which was done according to Sheng and Azevedo [20], were used to determine the energy value stated in terms of higher heating value (HHV) of samples.

\subsection{Thermogravimetric Analysis (TGA) of the samples}

A thermogravimetric analyzer (TGA) is used to determine the thermal behaviour of biomass materials. TGA determines the percentage weight loss of the biomass as a function of temperature, and the resulting thermos-gram has a unique shape for biomass materials [21]. This experiment was performed to examine the thermal behaviour of the samples and to determine the thermal factors that influence the gasification of the material. Thermogravimetric analyzer experiments are performed in a chemically inactive environment to demonstrate the effect of heat degradation [21].

\section{The Fluidised Bed Reactor}

\subsection{Overview and specifications}

Before using biomass in energy conversion systems, it is important to understand its composition. To characterize the composition of biomass, the proximate and ultimate analyses is commonly utilised, and different markers are frequently used to measure these components. The analysis was conducted in accordance with industry standards [22], [23], [24]. The amount of gas produced by the device is $2 \mathrm{~m}^{3} / \mathrm{kg}$ biomass, which produces about $0.75 \mathrm{kWh}$ with energy consumption rate $(\mathrm{kg} / \mathrm{hr})$ about $12 \mathrm{~kg}$. The dimensions of the device are $0.61 \mathrm{~m}$ height and $0.43 \mathrm{~m}$ diameter. Table 2 shows the findings of the proximate and ultimate analyses of the samples.

Table 2: Proximate and Ultimate Analysis of the Samples

\begin{tabular}{|c|c|c|c|c|}
\hline Characteristics & Sawdust & $\begin{array}{l}\text { Switch } \\
\text { grass }\end{array}$ & $\begin{array}{l}\text { Cocoa } \\
\text { pod } \\
\text { husks } \\
\end{array}$ & Bagasse \\
\hline \multicolumn{5}{|l|}{$\begin{array}{l}\text { Proximate } \\
\text { analysis }(w t \%)\end{array}$} \\
\hline $\begin{array}{l}\text { Moisture } \\
\text { content (dry } \\
\text { basis \%) }\end{array}$ & 11.8 & 9.70 & 12.66 & 9.51 \\
\hline $\begin{array}{l}\text { Ash content } \\
(\%)\end{array}$ & 1.10 & 4.62 & 7.97 & 1.94 \\
\hline $\begin{array}{l}\text { Volatile matter } \\
\text { content } \%\end{array}$ & 68.05 & 70.36 & 60.95 & 74.98 \\
\hline $\begin{array}{l}\text { Fixed to carbon } \\
\text { content } \%\end{array}$ & 19.05 & 15.02 & 18.42 & 13.57 \\
\hline \multicolumn{5}{|l|}{$\begin{array}{l}\text { The ultimate } \\
\text { analysis (wt \%) }\end{array}$} \\
\hline $\begin{array}{l}\text { Calorific value } \\
(\mathrm{MJ} / \mathrm{kg})\end{array}$ & 17.17 & 17.31 & 20.5 & 16.6 \\
\hline $\mathrm{C}$ & 44.11 & 43.19 & 39.87 & 44.1 \\
\hline $\mathrm{H}$ & 5.53 & 5.74 & 5.96 & 5.7 \\
\hline $\mathrm{O}$ & 45.52 & 50.2 & 45.33 & 47.7 \\
\hline $\mathrm{N}$ & 2.14 & 0.57 & 0.74 & 0.2 \\
\hline $\mathrm{S}$ & 2.7 & 0.3 & 0.13 & 2.3 \\
\hline
\end{tabular}

\subsection{Fluidised bed reactor operation}

All of the key electrical devices were installed in a panel box, which was mounted to the side of the reactor's frame (Figure 3 ). The heater was positioned 
near the reaction chamber, and the feeder was installed on the feed port. A pipe linked the gas collector to the reactor's flume, then ran to the bottom of the gas collector to bubble the water. The raw material was fed to the reactor through the feeder located beside the gasifier after sizing and drying. After a few minutes, the heater was switched on to speed up the ignition. To separate char particles, the hot gas exits the reactor and passes through a cyclone and a filter. The temperature and gas concentration is monitored using sensors designed for this purpose.

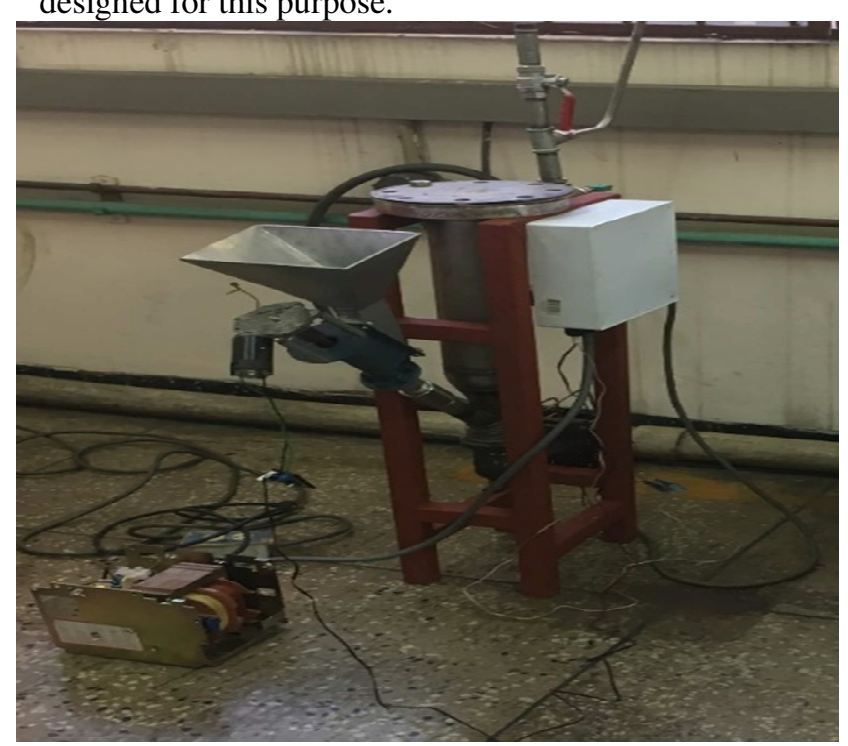

Fig. 3. Experimental Set up of the Fluidised Bed Reactor

\subsection{Experimental Procedures}

1. To guarantee that the biomass samples were bone dry when tested, they were dried in an oven at $70^{\circ} \mathrm{C}$ for four days. To prevent the samples from reabsorbing moisture after drying, the samples were stored in a sealed container. It was done as a precaution to get the best results, as moisture in the sample might reduce the machine's performance.

2. The compressor was put on and the regulator was adjusted until a flow rate of air was 9 liters/minute. This flow rate provides just enough fluidisation to the reaction chamber samples.

3. The Cooling fan was activated from the cooling box.

4. The circuit was activated. It activates the heater as well as the feeder, which is set to a specific temperature.

5. The temperature on the outside of the reaction chamber was measured using IR Gun.

6. Turn on the gas analyzer and insert it into the gas collecting chamber's exhaust port.

7. When the IR gun indicates that the reaction chamber temperature is $450^{\circ} \mathrm{C}$, add the $75 \mathrm{~g}$ of biomass to the hopper.

8. For $7 \mathrm{~min}$, take measurements from the gas analyzer every minute.

9. Turn off the circuit and let the reactor to cool, but keep the air running to burn off any extra char.

10. Repeat procedures 2 to 9 with the remaining samples.

11. Once the initial samples have been completed. Add the silicon dioxide $\left(\mathrm{SiO}_{2}\right)$ and nickel $(\mathrm{Ni})$ catalysts to the reactor and repeat steps 2 and 9 for each sample.

\section{Results and Discussion}

\subsection{Samples without Catalysts}

Table 3 shows the properties of syngas produced from the gasification of samples without catalysts.

Table 3: Properties of Syngas Produced from Gasification of Samples without Catalysts

\begin{tabular}{|l|l|l|l|l|}
\hline \multicolumn{1}{|c|}{ Properties } & \multicolumn{4}{|c|}{ Samples } \\
\hline & Sawdust & $\begin{array}{l}\text { Cocoa } \\
\text { pod } \\
\text { husks }\end{array}$ & Bagasse & $\begin{array}{l}\text { Switch } \\
\text { Grass }\end{array}$ \\
\hline Efficiency \% & 62.6 & 34.1 & 77.8 & 68.2 \\
\hline $\mathrm{CO} \%$ & 12.3 & 11.06 & 6.047 & 10.82 \\
\hline ST $\left({ }^{\circ} \mathrm{C}\right)$ & 56 & 81 & 58 & 68 \\
\hline $\mathrm{NO}$ ppm & 10 & 66 & 47 & 57 \\
\hline $\mathrm{HC}$ ppm & 3576 & 7928 & 1679 & 3856 \\
\hline $\mathrm{CO}_{2} \%$ & 11.7 & 13.3 & 13.8 & 17.5 \\
\hline Air/Fuel Ratio & 11.22 & 10.24 & 13.5 & 12.2 \\
\hline
\end{tabular}

\subsection{Samples with Catalysts}

Table 4 shows the properties of syngas produced from the gasification of samples with catalysts.

Table 4: Properties of Syngas Produced from Gasification of Samples with Catalysts

\begin{tabular}{|l|l|l|l|l|}
\hline \multicolumn{1}{|c|}{ Properties } & \multicolumn{4}{|c|}{ Samples } \\
\hline & Sawdust & $\begin{array}{l}\text { Cocoa } \\
\text { pod } \\
\text { husks }\end{array}$ & Bagasse & $\begin{array}{l}\text { Switch } \\
\text { Grass }\end{array}$ \\
\hline Efficiency \% & 74.7 & 53.8 & 76.5 & 64.9 \\
\hline $\mathrm{CO} \%$ & 6.19 & 2.97 & 6.83 & 8.36 \\
\hline ST $\left({ }^{\circ} \mathrm{C}\right)$ & 6.19 & 65 & 143 & 238 \\
\hline NO ppm & 18 & 18 & 29 & 31 \\
\hline $\mathrm{HC}$ ppm & 961 & 4702 & 1089 & 1844 \\
\hline $\mathrm{CO}_{2} \%$ & 11 & 13.8 & 12.5 & 11.3 \\
\hline Air/Fuel Ratio & 13.5 & 12.52 & 13.5 & 12.36 \\
\hline
\end{tabular}

The hydrocarbon generated by each sample is compared in Figure 4. Cocoa pod husks had the greatest hydrocarbon content at $7928 \mathrm{ppm}$, whereas bagasse had the lowest at $1679 \mathrm{ppm}$. Sawdust and switch grass generate $3576 \mathrm{ppm}$ and $3856 \mathrm{ppm}$ hydrocarbon respectively.

In the conversion of cocoa pod husks in a fixed-bed electric thermal reactor, biofuels and gas have higher average calorific values than other fuels like coal and ethanol [25]. It was discovered that cocoa pod husks were more suitable for biochemical conversion during the thermochemical characterisation of agricultural waste from West Africa [26]. Mancini et al [27] verified this, demonstrating that cocoa pod husks have high potential for syngas generation with cumulative 
methane outputs. The heating values of cocoa pod husks vary from 17 to $22 \mathrm{MJ} / \mathrm{kg}$ [28].

The syngas from the reactor proved combustible when the hydrocarbon value was above $3000 \mathrm{ppm}$, according to observations made during the experiment. Figure 5(a) shows the syngas produced from the gasification of cocoa pod husks while Figure 5 (b) shows the flame generated when the syngas was ignited. As a result, the reactor was able to convert the biomass into hydrogen, methane, and other alkane family members. The HC's highest value was determined to have a Lower Explosive Limit (LEL) of 0.8 percent [29]. This value was enough to ignite a flame in testing, but it was well beyond the range of any possible gas candidates to be deemed explosive.

The Lower Explosive Limit is the lowest concentration of a gas or vapour that will burn in air. It varies from gas to gas, but for flammable gases it is less than $5 \%$ by volume.

ISO10156 are the standards that specify LEL levels. IEC60079 standard puts 100 percent LEL as 4.4 percent by volume, but the ISO standard sets it at 5\% [30].

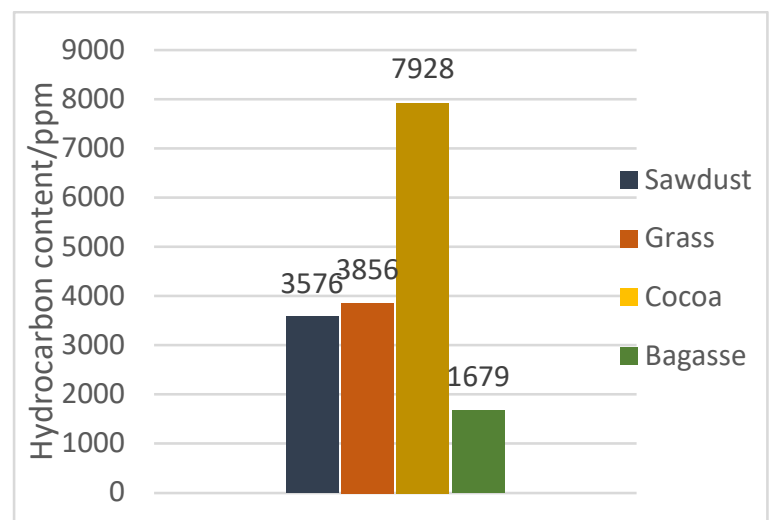

Fig. 4. Comparison of HC produced by samples without catalysts

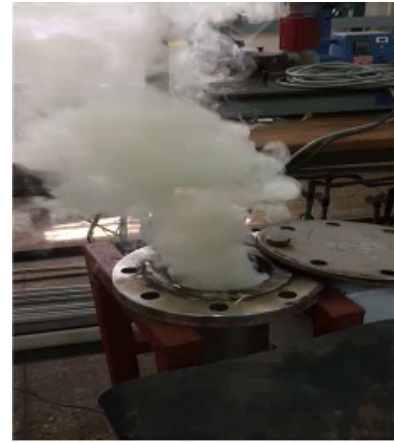

(a)

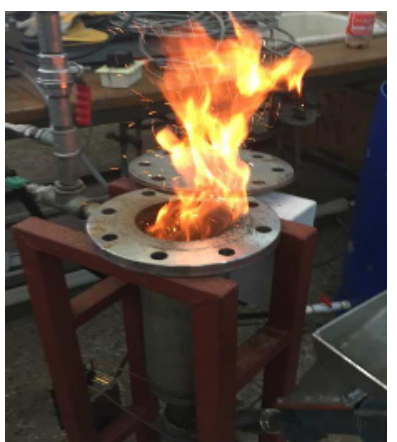

(b)
Fig. 5. (a) Syngas produced from gasification of cocoa pod husks experiment, (b) Flame generated when the tested syngas was ignited

As shown in Figure 6, cocoa pod husks with catalysts produced $4702 \mathrm{ppm}$ hydrocarbon while cocoa pod husks without catalysts produce 7928 ppm. Sawdust, bagasse and switch grass with catalysts also has a lower value of 961 ppm, 1089 ppm, and 1844 ppm, respectively. The hydrocarbon levels in the samples without catalysts were greater than in the ones with catalysts. HC conversion over Nickel/Silicon dioxide rose until $750^{\circ} \mathrm{C}$, after which it decreased as the reaction temperature climbed. The catalysts, prevent the production of tar and other heavier hydrocarbons. A catalyst is a component of a process that lowers the activation energy and hence increases the reaction rate. The reaction does not consume the catalysts.

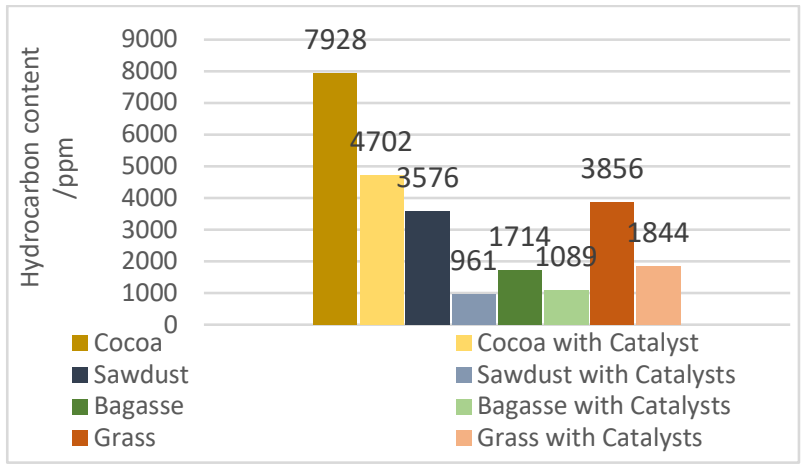

Fig. 6. Comparison of the HC produced by samples with and without Catalysts

The biomass was transformed into more hydrogen and lighter hydrocarbons since the heavier hydrocarbons were not produced.

As the gases travel through the nickel and silicon dioxide catalyst, molecules "stick" to the surface of the catalyst and react. Because the catalyst maintains the molecules close together to allow them time to react, the more surface area accessible, the more possibilities for reactions.

Figure 7 depicts the carbon monoxide \% at the top of the $\mathrm{HC}$ value. The $\mathrm{CO}$ levels in the samples without catalysts were significantly higher than in the samples with catalysts. Sawdust without catalysts generated a greater $\mathrm{CO}$ value $(12.3 \%)$, but sawdust with catalysts produced a $\mathrm{CO}$ value of 6.19 percent. Cocoa pod husks with catalysts generated the lowest $\mathrm{CO}$ value of 2.97 percent.

In the presence of a catalyst, both reverse and forward rate of reaction will accelerate, allowing the experiment to reach equilibrium faster, though the existence of a catalyst has no effect on the reaction's eventual equilibrium state. It just speeds up the whole process. The amount of $\mathrm{CO}$ generated decreases with time because the biomass burns off, leaving much less fuel in the reactor, resulting in less $\mathrm{CO}$ being produced.

Figure 8 shows $\mathrm{CO}_{2}$ gas output from the reactor at peak HC levels for each sample, as well as samples with and without catalysts. Switch grass generated the greatest $\mathrm{CO}_{2}$ value of 17.5 percent without catalysts, whereas switch grass with catalysts produced 11.3 percent. Sawdust with catalysts created the least amount of $\mathrm{CO}_{2}$, at 11 percent. Because of this information, samples with catalysts were more efficient at biomass conversion than ones without. When the efficiency of the samples in Tables 3 and 4 was compared, this inference was confirmed. Catalyst-containing samples are more efficient than non-catalyst-containing ones.

Figure 9 shows the Air/Fuel Ratios for each sample during the time when the $\mathrm{HC}$ values were at their highest. As can be observed from the graph, the smaller the Air/Fuel ratio, the higher the $\mathrm{HC}$ values. The A/F 
ratios likewise increased during the experiment, indicating that the fuel was being burnt off and that more air was being introduced into the system, diluting the product gas.

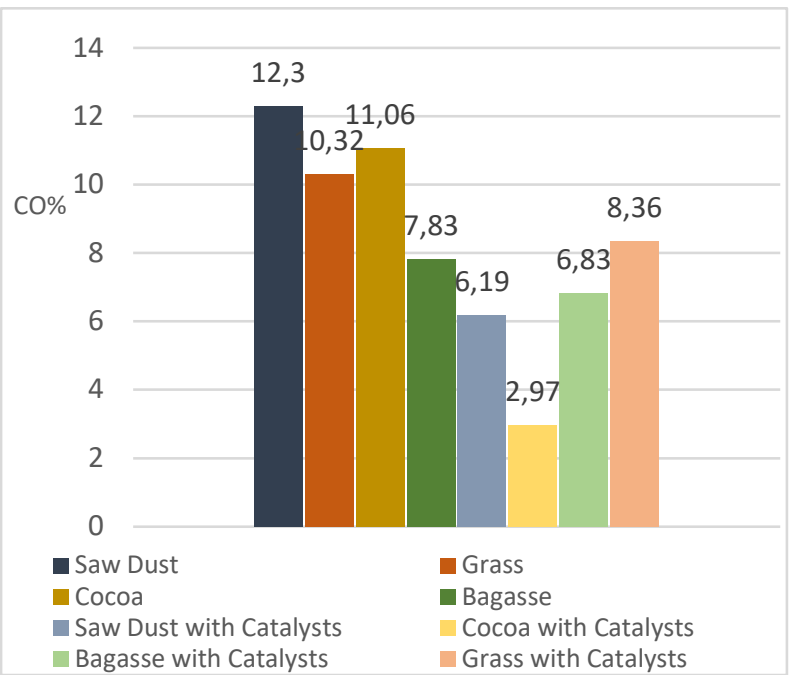

Fig. 7. Comparison of the $\mathrm{CO}$ produced by samples with and without Catalysts

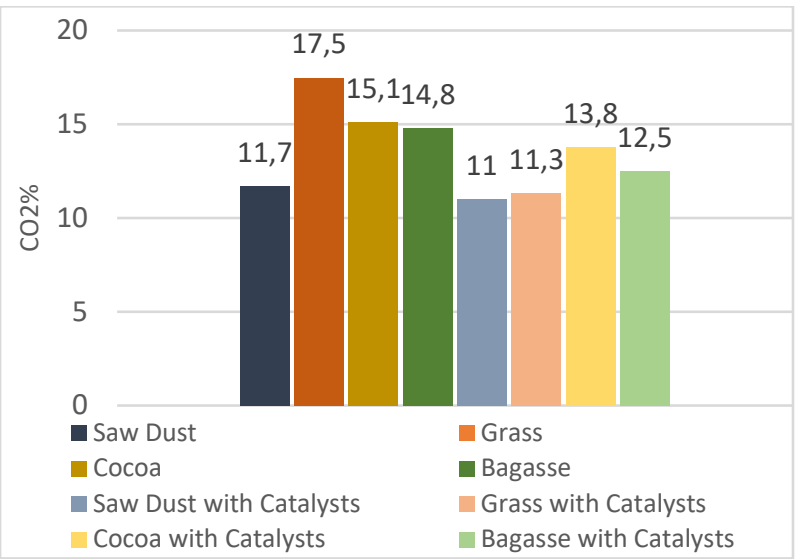

Fig. 8. Comparison of $\mathrm{CO}_{2}$ produced by samples with and without Catalysts

Figure 9 also shows that the samples with catalysts had greater $\mathrm{A} / \mathrm{F}$ ratios than the ones without, indicating that the catalyst-assisted process is more efficient, creating lighter hydrocarbons and hydrogen.

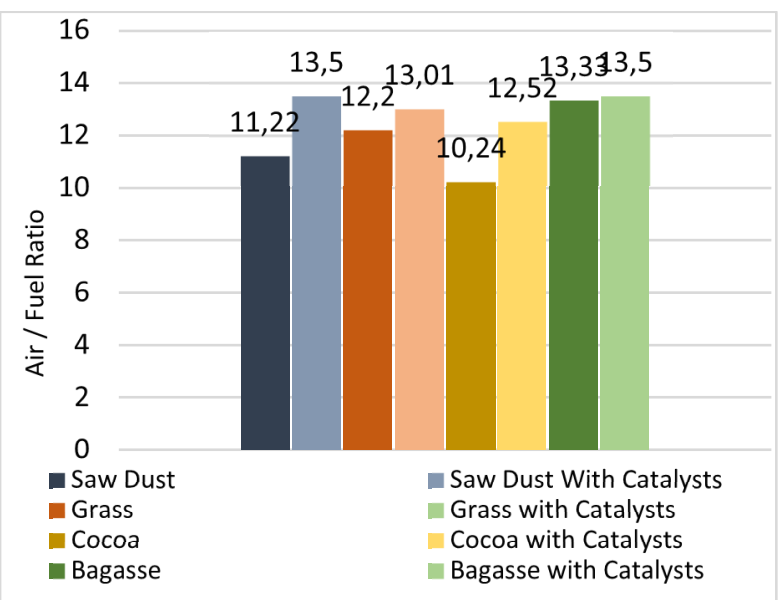

Fig. 9. Comparison of the Air/Fuel Ratio by samples with and without Catalysts

\section{Conclusion}

The impacts of nickel and silicon dioxide catalysts on the gasification of cocoa pod husks and other biomass wastes for syngas generation, as well as the investigation of raw material properties, were examined in this study. Due to their high volatile matter and cellulose content as well as low moisture content, the samples (sawdust, switch grass, cocoa pod husks, and bagasse) were found to be appropriate for use in the generation of syngas. The findings of the experimental study revealed that high hydrogen content in cocoa pod husks resulted in a higher syngas heat value, whereas gravimetric analysis revealed that high cellulose and hemicellulose content resulted in a greater concentration of hydrogen gas. The samples' thermal behaviour during gasification was divided into three phases, the first of which indicated the reduction of moisture content. In the second step, cellulose, hemicellulose, and lignin decomposition occurred. After 400 degrees Celsius, the carbonaceous and residual materials decomposed in the third stage. The composition of hydrogen rose as the temperature of the gasifier increased, but the percentage of carbon monoxide dropped. To create excellent quality gas from various forms of solid waste, the influence of operating duration on the syngas composition was examined. After roughly 30 minutes of gasifier operation, the quality of syngas began to deteriorate. As a result, each maximum capacity run should be limited to only $30 \mathrm{~min}$ before requiring refeeding.

\section{References}

1. Barbuzza E., Buceti G., Pozio A., Santarelli M., Tosti S., Gasification of wood biomass with renewable hydrogen for the production of synthetic natural gas, Fuel, 242, 520 - 531. (2019) DOI: 10.1016/j.fuel.2019.01.079

2. Masnadi M.S., Grace J.R., Bi X.T., Lim C.J., Ellis N., From fossil fuels towards renewables: Inhibitory and catalytic effects on carbon thermochemical conversion during cogasification of biomass with fossil fuels, Applied Energy, 140, 196-209 (2015)

3. Kamble A.D., Saxena V.K., Chavan P.D., Mendhe V.A. Co-gasification of coal and biomass an emerging clean energy technology: Status and prospects of development in Indian context, International Journal of Mining Science and Technology, 29, 171-186 (2019)

4. Nie F., Meng T., Zhang Q. Pyrolysis of LowRank Coal: From Research to Practice, in: Pyrolysis, InTech (2017)

5. Materazzi M., Lettieri P. Fluidized Beds for the Thermochemical Processing of Waste, in: Reference Module in Chemistry, Molecular Sciences and Chemical Engineering (2017)

6. Matsakas L., Gao Q., Jansson S., Rova U., Christakopoulos P. Green conversion of municipal solid wastes into fuels and 
chemicals, Electronic Journal of Biotechnology, 26, 69-83 (2017)

7. Lynd, L.R; Cushman, J.H; Nichols, R.J. and Wyman, C.E. "Fuel Ethanol from Cellulosic Biomass," Science, 251, 4999, 1318-1323 (1991)

8. Lynd, L.R; van Zyl, W.H; McBride, J.E. and Laser, M. "Consolidated Bioprocessing of Cellulosic Biomass: An Update. Current Opinion in Biotechnology," Curr Opin Biotechnol., 16, 5, 577-83 (2005)

9. Gasification Technologies Council "Gasification: Redefining Clean Energy," available online: http://www.gasification.org/.

10. Zhang, L; (Charles) $\mathrm{Xu}, \mathrm{C}$. and Champagne, P. "Overview of Recent Advances in ThermoChemical Conversion of Biomass," Energy Conversion and Management, 51, 969-982 (2010)

11. Puig-Arnavat M., Bruno J.C., Coronas A. Review and analysis of biomass gasification models, Renewable and Sustainable Energy Reviews, 14, 2841-2851 (2010)

12. Gómez-Barea A., Leckner B. Modeling of biomass gasification in fluidized bed, Progress in Energy and Combustion Science, 36, 444-509 (2010)

13. Basu, Prabir. Biomass gasification, pyrolysis and torrefaction: practical design and theory. Academic press (2018)

14. Rajvanshi, Anil K. "Biomass gasification." Alternative energy in agriculture 2 (4): 82102 (1986)

15. Bridgwater, A. V. "Catalysis in thermal biomass conversion." Applied Catalysis A: General 116 (1-2): 5-47 (1994)

16. Abu El-Rub, Ziad, Eduard A Bramer, and Gerrit Brem. "Review of catalysts for tar elimination in biomass gasification processes." Industrial \& engineering chemistry research 43 (22): 6911-6919 (2004)

17. Donkoh A, Atuahene C, Wilson B, Adomako D. Chemical composition of cocoa pod husk and its effect on growth and food efficiency in broiler chicks. Anim Feed Sci Technol. 35:161-169 (1991)

18. Figuiera, A; Janick, J and BeMiller J. New products from Theobroma cacao: Seed Pulp and Pod Gum. New Crops. Wiley, New York (1993)

19. Tanger, J.L; Field, C.E; Jahn, M.W; DeFoort, and Leach, J.E. "Biomass for thermochemical conversion: targets and challenges," Frontiers in Plant Science, Vol. 4, article 218 (2013)

20. Sheng, C. and Azevedo, J.L.T. "Estimating the higher heating value of biomass fuels from basic analysis data," Biomass \&Bioenergy, Vol. 28, No. 5, 499-507 (2005)

21. Anukam, S; Mamphweli, E; Meyer, and Okoh, O. "Computer simulation of the mass and energy balance during gasification of sugarcane bagasse," Journal of Energy, Vol. 2014, Article ID713054, 9 pages (2014)

22. ASTM E871 - 82 Standard Test Method for Moisture Analysis of Particulate Wood Fuels (2013)

23. ASTM D1102 - 84 Standard Test Method for Ash in Wood (2013)

24. ASTM E872 - 82 Standard Test Method for Volatile Matter in the Analysis of Particulate Wood Fuels (2013)

25. Chan, S. Y; and Choo, W. S. "Effect of extraction conditions on the yield and chemical properties of pectin from cocoa husks," Food Chemistry 141(4), 3752-3758 (2013)

26. Titiloye, J. O; Bakar, M. S. A; and Odetoye, T. E. "Thermochemical characterisation of agricultural wastes from West Africa," Industrial Crops and Products 47, 199-203 (2013)

27. Mancini, G; Papirio, S; Lens, P. N. L; and Esposito, G. Solvent pre-treatments of lignocellulose materials to enhance biogas production: a review. Energy Fuels 30, 18921903 (2016)

28. Syamsiro, M; Hu, W; Komoto, S; Cheng, S; Noviasri, P; Prawisudha, P. and Yoshikawa, K. Co-production of liquid and gaseous fuels from polyethylene and polystyrene in a continuous sequential pyrolysis and catalytic reforming system. Energy and Environment Research. 3(2):90-106 (2013)

29. Box, Engineeering Tool. Solubility of Gases in Water. Accessed 4 7, (2019) https://www.engineeringtoolbox.com/gasessolubility-water-d 1148.html.

30. ISO 10156. Determination of fire potential and oxidising ability for the selection of cylinder valve outlets. International Standard. Switzerland (2017) 